\title{
Morphometric and endocrine analyses of the effects of nutrition on the testis of mature Merino rams
}

\author{
M. J. Hötzel ${ }^{1 *}$, C. M. Markey ${ }^{2}$, S. W. Walkden-Brown ${ }^{1 \dagger}$, \\ M. A. Blackberry ${ }^{1}$ and G. B. Martin ${ }^{1 \ddagger}$ \\ ${ }^{1}$ Faculty of Agriculture (Animal Science), University of Western Australia, Nedlands, WA 6907, Australia; \\ and ${ }^{2}$ Department of Anatomy and Human Biology. The University of Western Australia, Nedlands,
}

WA 6907, Australia

\begin{abstract}
The effects of nutrition on the testis were investigated in groups of five mature Merino rams that were fed either a sub-maintenance (low) diet or a supra-maintenance (high) diet for 69 days. Testosterone, oestradiol and inhibin were measured in blood plasma sampled simultaneously from jugular and testicular veins after an i.v. injection of $200 \mathrm{ng}$ ovine $\mathrm{LH}$ $\mathrm{kg}^{-1}$. Plasma concentrations of testosterone, inhibin and oestradiol were higher in testicular than in jugular vein plasma for both diets $(P<0.01)$. After the LH injection, jugular plasma testosterone increased more rapidly $(P<0.01)$ in rams fed the high diet than in rams fed the low diet. This was not seen in the testicular vein. Oestradiol concentrations were higher in rams on the high diet than in those on the low diet, in both the testicular $(P<0.0001)$ and the jugular vein $(P<0.02)$. Diet did not affect inhibin concentrations. Testes were surgically removed and processed for light microscopy. Testicular mass and seminiferous tubule length and diameter were higher with the high diet than the low diet $(P<0.01)$. The number of Sertoli cell nuclei per testis was also affected (high diet: $120 \pm 6 \times 10^{8}$; low diet: $77 \pm 7 \times 10^{8} ; P<0.001$ ), whereas the proportion of testis occupied by Sertoli cell nuclei was not affected. The number of Leydig cells per testis was not affected by diet, but Leydig cells occupied a greater volume of testis in rams on the high diet than in those on the low diet $(P<0.001)$. The effects of nutrition on Leydig and Sertoli cells are consistent with changes in the endocrine and exocrine functions of the testis. The finding that Sertoli cell population was altered in adult rams may be explained by the $\mathrm{GnRH}$-independent effects of nutrition.
\end{abstract}

\section{Introduction}

It is well established that nutrition affects testicular size (Moule, 1963; Salamon, 1964; Setchell et al., 1965; Parker and Thwaites, 1972; Braden et al., 1974; Alkass et al., 1982; Masters and Fels, 1984; Martin et al., 1994a) and the production of spermatozoa in rams (Oldham et al., 1978; Cameron et al., 1988; Pomares et al., 1991). In contrast, the endocrine function of the testis does not appear to be affected in the same way. Peripheral concentrations of testosterone are influenced by diet as a result of changes in LH pulsatility (Martin et al, 1994a, b) but changes in testicular size induced by nutrition do not affect LH-induced changes in plasma testosterone concentrations (Ritar et al., 1984; Martin et al., 1987, 1994a; Hötzel et al., 1993, 1995). These data contradict an earlier study describing a reduction in

\footnotetext{
*Present address: Departomento de Zootecnia, Centro de Ciências Agrárias, Universidade Fedral de Santa Catarina, Caixa Postal 476, Rodovia SC $404 \mathrm{~km}$ 13, Bairro Itacorubi, Florianópolis, SC, Brazil.

${ }^{\dagger}$ Present address: Department of Animal Science, University of New England, Armidale, NSW 2351, Australia.

${ }^{\ddagger}$ Correspondence.
}

Received 4 July 1997. testosterone secretion in rams that had been subjected to a long and severe period of undernutrition (Setchell et al, 1965). Changes in diet, to amounts higher or lower than those required for maintenance of body mass, also failed to affect jugular inhibin concentrations in the ram (Martin et al., 1994a; Hötzel et al., 1995) but production of inhibin might be affected by a more stringent nutritional treatment. There is no information on the effects of nutrition on circulating concentrations of oestradiol, another hormone secreted by the testis of the ram (Pope et al., 1990) that appears to play a role in the control of gonadotrophin secretion. Therefore, it is hypothesised that larger changes in nutrition than those used in our previous studies are required to affect testosterone and inhibin concentrations, and that such changes would also affect oestrogen production.

Measurement of metabolic clearance rates and blood flow through the testis can be used to test this hypothesis, as these are two factors likely to be affected by diet and also likely to influence circulating concentrations of the hormones secreted by the testis (Setchell et al., 1965; Adams et al., 1994). One way of avoiding the problem of changes in metabolic clearance rate is to measure these hormones in blood sampled from the testicular circulation. As a result of arterio-venous anastomoses 
located in the pampiniform plexus of the spermatic cord of rams, up to $60 \%$ of the arterial blood is transferred to the veins, thus decreasing the hormone concentrations as blood leaves the testis through the spermatic cord (Wensing et al., 1981; Noordhuizen-Stassen et al., 1985; Maddocks et al., 1993). Sampling blood from the veins in the surface of the anterior pole of the testis avoids this problem and gives the most accurate indication of intratesticular concentrations of hormones (Maddocks et al., 1993). These veins are easy to access in rams and so were chosen as the sampling site in the present study testing our hypothesis that nutrition affects the production of testosterone, inhibin and oestradiol.

The effects of nutrition on the exocrine and endocrine compartments of the testis are certain to be associated with changes in the testicular tissues. The few reports available have shown that the volume of seminiferous epithelium and the diameter of the seminiferous tubules are affected (Setchell et al., 1965; Oldham et al., 1978; Pomares et al., 1991). However, there are no data describing the changes in the principal cell types in the testis: the Sertoli cells, which nurture germ cells and secrete inhibin and, probably, oestradiol; and the Leydig cells, which produce the androgens necessary for the completion of spermatogenesis. If, as hypothesized, nutrition affects testosterone secretion, the number and size of Leydig cells would be expected to change. However, the number of Sertoli cells appears to be established some time before puberty (Monet-Kuntz et al., 1984), and so a change in cell size would be expected to support the concomitant changes in production of spermatozoa.

The present study investigated the effects of dietary manipulation on the endocrine function and morphometry of the ram testis, with particular emphasis on relationships between changes in structure and function, to enable further understanding of the effects of nutrition on the reproductive axis.

\section{Materials and Methods}

\section{Animals and treatments}

Mature Poll Merino rams (36 months old, $67.2 \pm 2.1 \mathrm{~kg}$ body mass, scrotal circumference of $34.5 \pm 0.8 \mathrm{~cm}$ ) were housed in individual pens under natural lighting at the University of Western Australia (latitude $31^{\circ} 56^{\prime} \mathrm{S}$ ), where photoperiod ranges from $10 \mathrm{~h}$ light: $14 \mathrm{~h}$ dark in winter to $14 \mathrm{~h}$ light:10 h dark in summer. During an acclimatization period of 3 weeks, the rams were fed $800 \mathrm{~g}$ of a basal diet consisting of a mixture of oaten chaff with $10 \%$ lupin grain (Lupinus angustifolius) and $3 \%$ complete mineral supplement. Food was provided once a day in the evening and water was available ad libitum.

In March (beginning of autumn), the rams were allocated to diets designed to produce loss or gain of $1 \mathrm{~kg}$ per week of body mass ( $n=5$ per group). The low diet consisted of $400 \mathrm{~g}$ day $^{-1}$ of the basal diet, and the high diet of $1 \mathrm{~kg}$ of the basal diet plus $1.5 \mathrm{~kg}$ lupins day ${ }^{-1}$. Body mass and scrotal circumference were measured weekly for the first 35 days and then at the end of the experiment (day 69, end of autumn). For the first 35 days of the experiment, all rams were used as controls for another study (Hötzel et al, 1995), for which they received a periodic i.v. infusion of heparinized saline $\left(5 \mathrm{iu} \mathrm{ml} \mathrm{ml}^{-1}\right.$ in $5 \mathrm{ml}$ every $3 \mathrm{~h}$ ). Thereafter, the dietary treatments were extended for another 35 days, to allow completion of the present study.

\section{Experimental procedures}

On day 69 of dietary treatment, the rams were anaesthetized and maintained in an upright position (approximate standing) by a body sling. General anaesthesia was induced with an i.v. injection of $15-25 \mathrm{ml} \mathrm{5 \%}$ thiopentone solution (Penthothal, Bomac Laboratories, NSW) and maintained with 3\% halothane in oxygen. This allowed blood to be sampled simultaneously from the jugular and testicular veins. At $-1,15,30,45,60,75$, 105 and $135 \mathrm{~min}$ relative to an intrajugular injection of ovine LH (NIADDK-oLH-25; $200 \mathrm{ng} \mathrm{kg}^{-1}$ bodyweight), blood was sampled simultaneously from the jugular and testicular veins. This timing was chosen on the basis of previous studies in which it had been established that testosterone concentrations return to basal values by $120 \mathrm{~min}$ after stimulation with exogenous LH (Martin et al., 1994a; Hötzel et al., 1995). Blood from the peripheral circulation was sampled through polyethylene catheters inserted in one jugular vein. Testicular vein samples were taken with 25 gauge hypodermic needles from any vein clearly visible on the surface of the dorsal pole of the testis. A central incision in the posterior aspect of the scrotum was used to expose one testis, which was replaced inside the scrotum between samples to maintain normal temperature and to minimize any effects on testicular blood flow. Small variations in the temperature of the testes do not affect testicular blood flow (Setchell et al., 1966).

\section{Tissue collection}

After the last blood sample was taken, the testes were surgically removed and the testis that was not used for blood collection was immediately preserved for histological analysis. The testis and epididymis were separated from the tunica vaginalis, perfusion fixed, dissected from each other and then weighed separately. The testes were perfused at room temperature via the spermatic artery with heparinized saline followed by approximately $500 \mathrm{ml}$ Karnovsky's fixative ( $2 \%(\mathrm{v} / \mathrm{v})$ paraformaldehyde, $2.5 \%(\mathrm{v} / \mathrm{v})$ glutaraldehyde in $0.1 \mathrm{~mol}$ phosphate buffer $1^{-1} ; \mathrm{pH} 7.4$ ). Between 10 and 15 blocks (each about $1 \mathrm{~mm} \times 2 \mathrm{~mm} \times 2 \mathrm{~mm}$ ) from various regions of the testis were excised. Five blocks were chosen randomly and post-fixed in Karnovsky's fixative, washed in $0.1 \mathrm{~mol}$ phosphate buffer $l^{-1}$, then post-fixed in $1 \%$ osmium sulphate in $0.1 \mathrm{~mol}$ phosphate buffer $1^{-1}$. The blocks were dehydrated with a series of washes in alcohol (50\%, 70\%, 90\% and 100\% (v/v)) and 100\% (v/v) acetone, infiltrated with a series of Epon-Araldite:acetone solutions, and finally embedded in Epon-Araldite. Blocks were trimmed and $1 \mu \mathrm{m}$ sections were cut with a glass knife on an LKB ultramicrotome. Sections were stained with $1 \%(\mathrm{w} / \mathrm{v})$ toluidine blue, mounted with a glass coverslip and examined using a Wild Leitz microscope.

\section{Morphometric analysis}

The cross-sectional diameter of the seminiferous tubules, the height of the spermatogenic epithelium and the diameter of the 
lumen of the seminiferous epithelium were measured by fitting a graticule of a calibrated linear scale in the $\times 10$ eyepiece of a Wild Leitz microscope at objective lens $\times 25$. In each section, only those tubules that were near circular in profile and that had a centrally located lumen were measured in two transverse dimensions of the tubules. Five tubules per section were measured in each of five tissue blocks (that is, 25 tubules per testis). Seminiferous tubule length was calculated assuming that seminiferous tubules are perfect cylinders, using the formula:

$$
L=\frac{V}{\pi r^{2}}
$$

where $L=$ length of tubules, $V=$ total volume of tubules, and $r=$ radius of tubules (estimated as half of the tubule diameter).

The volume fractions of testis occupied by spermatogenic epithelium and interstitial tissue, blood and lymph vessels and Leydig and Sertoli cells were determined by the point-counting method (Weibel, 1979) using a graticule containing a multipurpose test system M42 on the eyepiece of a Wild Leitz microscope. Tissue was viewed at $\times 40$ (spermatogenic and interstitial tissues and vessels) or $\times 100$ magnification (cells). All tissue variables were assessed by viewing four areas chosen randomly in five sections from each of the five blocks of tissue so that a total of 100 areas was measured from each testis. The volume fraction of each component $\left(V_{V i}\right)$ was calculated as the ratio of the number of points lying on the component $i(P)$ and the total number of points $\left(P_{T}\right)$ within the lattice $\left(V_{V_{i}}=P_{i} / P_{T}\right)$. The total volume of a tissue was calculated by multiplying the volume fraction by the total volume of testicular tissue $\left(V_{V i} \times\right.$ testicular mass).

The number of Sertoli and Leydig cells per unit volume of testis was estimated using the equation:

$$
N_{V_{i}}=\frac{K}{B} \times \sqrt{\frac{\left[N_{A_{i}}\right]^{3}}{V_{V_{i}}}}
$$

The number of structures (i) per unit area $\left(N_{A i}\right)$ was calculated as:

$$
N_{A i}=\frac{N_{i}}{A_{T}}
$$

where $N_{i}$ is the total number of transactions of the structure recorded in the area $A_{T}$ covered by the counting field. The factor $K$ depends on the relative size distribution of the structure. Assuming that biological studies generally show a narrow size distribution, and given the comparative nature of the present study, $K$ was given a value of 1 . The factor $B$ depends on the shape of the structure, such that it relates the volume to the cross-sectional area $(a)$ of the structure:

$$
v=B \sqrt{ } a^{3}
$$

Neither Leydig cells nor Sertoli cells are spherical but, again, given the comparative nature of the study, $B$ was given a value of 1 . The total number of each cell type per testis was calculated by multiplying its numerical density by the total testicular volume. The numbers of Sertoli and Leydig cells per
Table 1. Morphometric analysis of the testicular tissue from mature Merino rams ( $n=5$ per group) fed a supra-maintenance (high) or a sub-maintenance (low) diet for 69 days

\begin{tabular}{lcc}
\hline Variable & High diet & Low diet \\
\hline Tubule diameter $(\mu \mathrm{m})$ & $229 \pm 6$ & $167 \pm 12^{\mathrm{c}}$ \\
Lumen diameter $(\mu \mathrm{m})$ & $69 \pm 3$ & $66 \pm 7$ \\
Tubule length $(\mathrm{m})$ & $3503 \pm 104$ & $2378 \pm 329^{\mathrm{b}}$ \\
Relative volume of testicular components $(\%)$ & \\
Seminiferous tubules & $85.9 \pm 1.4$ & $75.0 \pm 4.1^{\mathrm{a}}$ \\
Seminiferous epithelium & $79.0 \pm 1.6$ & $67.7 \pm 5.1$ \\
Tubular lumen & $6.8 \pm 1.2$ & $7.3 \pm 1.4$ \\
Interstitial tissue & $14.1 \pm 1.4$ & $25.0 \pm 4.1^{\mathrm{a}}$ \\
Blood vessels & $2.2 \pm 0.3$ & $2.1 \pm 0.2$ \\
Lymph vessels & $1.8 \pm 0.3$ & $2.4 \pm 0.3$ \\
Leydig cells & $5.7 \pm 0.5$ & $8.3 \pm 0.6^{\mathrm{c}}$ \\
Leydig cell nucleus & $0.4 \pm 0.1$ & $0.5 \pm 0.1$ \\
Leydig cell cytoplasm & $5.3 \pm 0.5$ & $7.8 \pm 0.7^{\mathrm{c}}$ \\
Sertoli cell nuclei & $2.5 \pm 0.4$ & $2.4 \pm 0.2$ \\
Total volume of testicular components (cm & \\
Seminiferous tubules & $247 \pm 9.0$ & $88 \pm 8.0^{\mathrm{c}}$ \\
Seminiferous epithelium & $227 \pm 10.0$ & $80 \pm 9.0^{\mathrm{c}}$ \\
Interstitial tissue & $42 \pm 6.0$ & $29 \pm 5.0^{\mathrm{b}}$ \\
Blood vessels & $6.3 \pm 1.1$ & $2.4 \pm 0.2^{\mathrm{b}}$ \\
Lymph vessels & $5.2 \pm 1.1$ & $2.9 \pm 0.5$ \\
Leydig cells & $16.2 \pm 1.4$ & $9.7 \pm 1.1^{\mathrm{b}}$ \\
Leydig cell cytoplasm & $15.1 \pm 11.3$ & $9.1 \pm 1.1^{\mathrm{b}}$ \\
Leydig cell nucleus & $1.2 \pm 0.1$ & $0.6 \pm 0.1^{\mathrm{b}}$ \\
Sertoli cell nucleus & $7.2 \pm 1.3$ & $2.8 \pm 0.2^{\mathrm{b}}$ \\
Total number per testis & & \\
Leydig cells $\left(\times 10^{8}\right)$ & & \\
Sertoli cells $\left(\times 10^{8}\right)$ & & $60 \pm 11$ \\
& & $77 \pm 7^{\mathrm{c}}$ \\
\hline
\end{tabular}

Mean with a superscript differs significantly from rams fed the high diet: ${ }^{a} P<0.05 ;{ }^{b} P<0.01$; ${ }^{C} P<0.001$.

testis that were derived by this method are in the upper range in the literature for the mature ram. For Leydig cells, that range is $4-95 \times 10^{8}$ per testis (Barenton and Hochereau-de Reviers, 1981; Pisselet et al., 1984; Hochereau-de Reviers et al., 1985, 1990). For Sertoli cells, the range is $13-110 \times 10^{8}$ per testis (Hochereau-de Reviers et al., 1985; Mirando et al., 1989).

An attempt was made to measure the cytoplasmic volume of the Leydig cells (Table 1). However, the boundaries were not clearly defined in $20 \%$ of the cells in the low diet and $25 \%$ in the high diet rams; this difference was not statistically significant, suggesting that it was the result of a technical problem rather than an effect of treatment. Therefore, only the cytoplasm of cells with clearly defined boundaries were included in the counting and only these data are presented. As a consequence, these values are, in fact, about $80 \%$ of the actual total volume of Leydig cells. For the estimate of the total number of Leydig cells per testis, the nuclei were always clearly identifiable and were counted. Tissue shrinkage was not corrected for because all testes were fixed by vascular perfusion (collection of unfixed tissue was not feasible), and because absolute values are not needed when the hypotheses are tested by comparisons among treatments. 


\section{Hormonal assays}

LH was measured in all jugular plasma samples collected on day 69 , and FSH was measured in the jugular plasma samples collected before the injection of oLH. Testosterone was measured in all jugular and testicular vein plasma samples and inhibin and oestradiol were measured in samples collected at $-\mathrm{I}, 60$ and $135 \mathrm{~min}$ after injection of oLH. Plasma concentrations of FSH and inhibin were measured in the same assays reported by Hötzel et al. (1995).

Plasma concentrations of LH were measured using the radioimmunoassay described by Martin et al. (1994a). The preparation CNRS-M3 (biopotency 1.8 iu NIH-LH-S1 $\mathrm{mg}^{-1}$ ) used for reference was kindly supplied by M. Jutisz (Collège de France). The tracer was prepared using NIDDK-oLH-I-3 donated by the National Institute of Diabetes, Digestive and Kidney Disease (Baltimore, MD). Antiserum RI was raised in a rabbit in our laboratory and had the following crossreactions: $100 \%$ with NIH-LH-S1, 97\% with NIH-LH-S20, 18\% with NIAMDD-oFSH-RP1，0.93\% with NIH-FSH-S12, $8.2 \%$ with oGH and 5\% with NIH-TSH-S8. The limit of detection of the standard curve (for all assays) was calculated by subtracting 2 so from the mean counts bound in nine replicates of the zero standard. The samples for LH were assayed in a single assay as duplicate $200 \mu \mathrm{l}$ aliquots, and the limit of detection was $0.125 \mathrm{ng} \mathrm{ml}^{-1}$. Intra-assay coefficients of variation were $3.3 \%$, $6.1 \%$ and $12.9 \%$, for quality controls containing $6.4,1.5$ and $0.7 \mathrm{ng} \mathrm{mI}^{-1}$, respectively.

Plasma concentrations of FSH were measured by the method described by Martin et al. (1994a), using a kit kindly supplied by A. F. Parlow of the National Institute of Diabetes, Digestive and Kidney Disease. The kit comprised antiserum oFSH-I, reference preparation oFSH-RP-I (biopotency 75 iu NIHFSH-SI $\mathrm{mg}^{-1}$ ) and tracer preparation oFSH-I-I. The samples were assayed as duplicate $200 \mu \mathrm{l}$ aliquots, and the limit of detection was $0.27 \mathrm{ng} \mathrm{ml}^{-1}$. The intra-assay variations (mean \pm SEM) were $9.75 \pm 0.75 \%, 10.2 \pm 1.6 \%$ and $12.3 \pm 1.6 \%$ for quality controls containing 4.44, 2.55 and $1.37 \mathrm{ng} \mathrm{ml}^{-1}$, respectively. The interassay coefficients of variation were $6.22 \%, 3.61 \%$ and $8.81 \%$, respectively.

Plasma testosterone was measured using a non-extraction radioimmunoassay developed in our laboratory (Hötzel et al., 1995). The antiserum (rabbit 3) was raised in our laboratory against testosterone-3-CMO-HSA. The preparation 4-androsten-17 $\beta$-ol-3-one; $10 \mu \mathrm{g} \mathrm{ml}^{-1}$ (Sigma Chemical Co., St Louis, MO) was used for reference and 1,2,6,7$\left[{ }^{3} \mathrm{H}\right]$ testosterone (Amersham International, Little Chalfont, Bucks) was the tracer. Crossreactions were 100\% with testosterone, $70 \%$ with dihydrotestosterone, $3.7 \%$ with androstenedione, and $<0.05 \%$ with progesterone, oestradiol, oestrone and oestriol. The samples were assayed as duplicate $25 \mu \mathrm{l}$ aliquots. The limit of detection of the assay was $0.2 \mathrm{ng} \mathrm{ml}^{-1}$ and the intra-assay coefficients of variation were $3.8 \%, 6.5 \%$ and $7.3 \%$ for quality controls containing 5.0, 2.7 and $1.6 \mathrm{ng}$ $\mathrm{ml}^{-1}$, respectively.

Plasma oestradiol concentrations were measured by a double-antibody radioimmunoassay developed by Webb et al. (1985). The antisera for the affinity chromatography and the radioimmunoassay, and the steroid used for the preparation of the tracer were kindly donated by R. Webb (AFRC Roslin
Institute, Edinburgh). Oestradiol powder dissolved in ethanol was used as reference. The antiserum used for the affinity chromatography was raised in sheep against oestradiol-17 $\beta-6$ carboxymethyl-oxime conjugated to egg albumin. The assay antiserum R48 was raised in rabbits against oestradiol-17 $\beta-$ oestradiol-11 $\beta$-succinyl-BSA. Major crossreactions were $16 \%$ with oestrone, $1.2 \%$ with testosterone, $3 \%$ with oestriol and $0.1 \%$ with $5 \alpha$-dihydrotestosterone. The tracer was prepared using the steroid conjugate $17 \beta$-oestradiol-11 $\alpha$-hemisuccinate. The samples were assayed as duplicate $500 \mu \mathrm{l}$ aliquots of resuspended serum. The limit of detection of the assay was $0.52 \mathrm{pg} \mathrm{ml}^{-1}$ and the intra-assay coefficients of variation were $7.6 \%, 9.3 \%$ and $16.4 \%$ for quality controls containing 14.5, 5.5 and $2.6 \mathrm{pg} \mathrm{ml}^{-1}$, respectively.

Concentrations of inhibin were measured using the double antibody radioimmunoassay described in detail by McNeilly et al. (1989). In brief, the antiserum (R150) was raised in a rabbit immunized against a synthetic $1-26$ sequence of the $\alpha$-chain of porcine inhibin. At a final dilution of 1:75000, it specifically bound $24 \%$ of labelled antigen. The synthetic peptide was used as reference and as a tracer after it was labelled with ${ }^{125}$ I by the chloramine-T method. An amount of inhibin-free plasma equivalent to that in the samples was added to each standard. The samples were assayed as duplicate $200 \mu \mathrm{l}$ aliquots, and the limit of detection was $0.08 \mathrm{ng} \mathrm{ml} \mathrm{ml}^{-1}$. All samples were measured in a single assay, which included six replicates of three pooled plasma samples containing inhibin at concentrations of $2.79,1.17$ and $1.55 \mathrm{ng} \mathrm{ml}^{-1}$. These samples were used to estimate the coefficients of variation within the assay (4.8, 6.1 and $4.4 \%$, respectively).

Areas under the response curves for testosterone and $\mathrm{LH}$ were calculated by summing the values for all times after subtracting the basal values (that is, the concentration measured before the injection of LH). The jugular: testicular ratios of concentrations of oestradiol, inhibin and testosterone were calculated by dividing the mean concentration in the testicular vein by the mean concentration in the jugular vein for each animal; subsequently, a mean and SEM for the group were calculated from the values from each of the five rams in each group.

\section{Statistical analysis}

Data were analysed by repeated measures ANOVA to test for interactions between the effects of diet and time on plasma FSH concentrations and on the changes in mean plasma concentrations of testosterone after the LH stimulus. One-way ANOVA was used to test for effects of diet on testosterone peak amplitude and mean concentrations, mean plasma concentrations of oestradiol and inhibin in testicular and jugular veins, and mean FSH concentrations on day 69. The effects of diet on bodyweight and testicular mass, and morphometric data were also analysed by one-way ANOVA.

Paired testicular mass on day - I was extrapolated from the day -1 scrotal circumference on that day using the regression equation $y=0.029 x+22.367$, where $y=$ scrotal circumference and $x=$ paired testicular mass, to determine the changes in testicular mass between day -1 and day 69 . The equation was 
calculated from the masses and scrotal circumferences of the 10 rams on day 69 of the experiment $\left(R^{2}=0.98 ; P<0.0001\right)$.

\section{Results}

\section{Bodyweight, testicular mass and scrotal circumference}

Bodyweight increased in rams fed the high diet and decreased in those fed the low diet so that, on the day of castration, the groups differed by about $30 \mathrm{~kg}(P<0.0002$; Fig. 1). Scrotal circumference also decreased in rams fed the low diet and increased in rams fed the high diet, so that they differed by $10 \mathrm{~cm}$ on day $69(P<0.0001$; data not shown). The testicular mass of rams fed the low diet was $40.7 \%$ of that of rams fed the high diet, and represented $0.74 \pm 0.04 \%$ (mean \pm SEM) of the total body mass of rams fed the high diet, and $0.49 \pm 0.04 \%$ in rams fed the low diet $(P<0.002$; Fig. I).

\section{Follicle stimulating hormone}

Repeated measures analysis of variance revealed effects of diet $(P<0.01)$ and time $(P<0.05)$, and the interaction between these effects $(P<0.001)$, on plasma concentrations of FSH (Fig. 2). The values doubled with the high diet between day -1 and day $35(P<0.01)$, but then declined until day 69 , by which time they did not differ significantly from the values observed on day -1 . With the low diet, FSH concentrations decreased steadily between day -1 and day 69 , when they were significantly lower than those observed in this group on day -1 $(P<0.05)$, and lower than those in the high diet on day 69 $(P<0.001)$.

Concentrations of testosterone, inhibin and oestradiol in plasma from the jugular and testicular veins

After the i.v. injection of oLH, peak LH concentrations (9.5-10.5 $\mathrm{ng} \mathrm{m}^{-1}$ ) were achieved by the first sample (15 min), after which there was a logarithmic-type decline leading to a return to basal values by $75 \mathrm{~min}$. The areas under the curve were $23.2 \pm 3.4$ (high diet) and $18.7 \pm 3.6$ (low diet) units and were not significantly different. Similarly, diet did not affect the mean plasma concentrations, the amplitude of the pulse, the time to the peak or the mean concentrations over the $135 \mathrm{~min}$ period of observations (data not shown).

Mean plasma concentrations of testosterone, inhibin and oestradiol were higher in testicular than in jugular vein plasma for both diets $(P<0.01$; Fig. 3). Mean plasma concentrations of oestradiol were significantly higher in rams fed the high diet than in those fed the low diet, in both testicular $(P<0.0001)$ and jugular veins $(P<0.02)$, and the ratio of testicular: jugular concentration was also significantly affected by $\operatorname{diet}(P<0.01$; Fig. 3). Plasma concentrations of inhibin were about twofold higher in the testicular vein than in the jugular vein, but were not significantly affected by diet at either sampling site (Fig. 3).

In jugular plasma, the mean concentrations of testosterone were higher $(P<0.01$; Fig. 3$)$ in rams fed the high diet than in those fed the low diet, as were the testosterone: $\mathrm{LH}$ ratios,
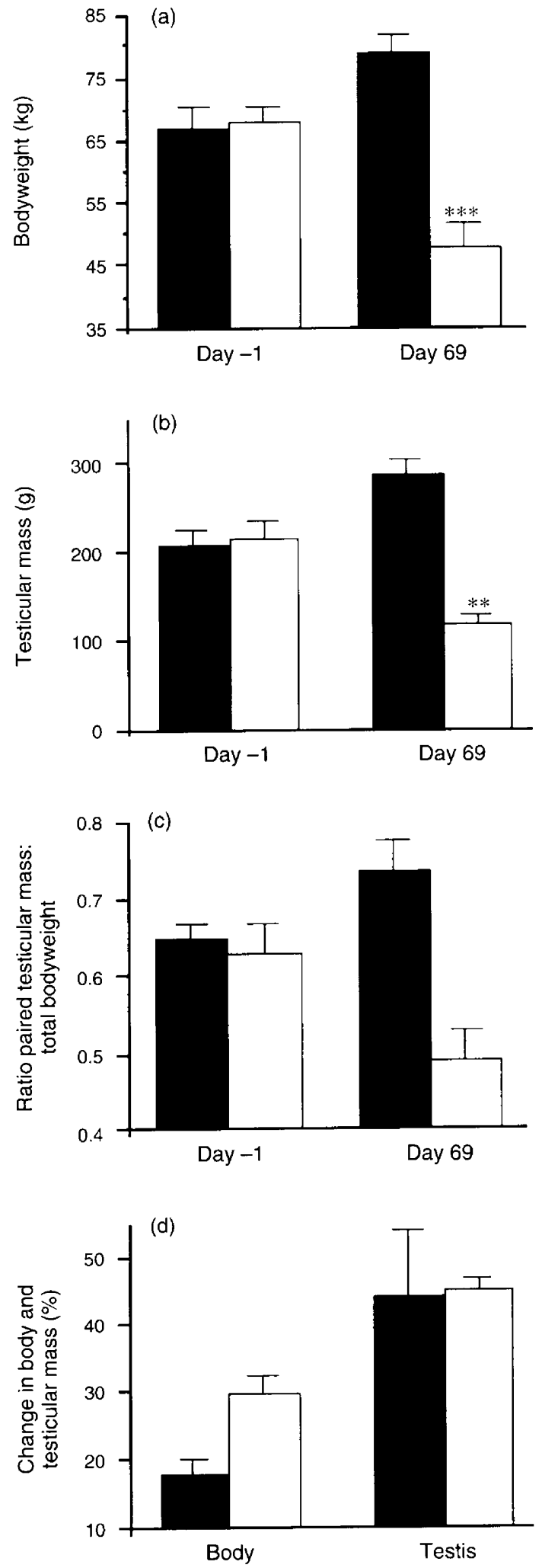

Fig. 1. Mean $\pm \operatorname{SEM}(n=5$ ) (a) bodyweight, (b) testicular mass and (c) the ratio of testicular to body weight in mature Merino rams fed a supra-maintenance (high, $\mathbf{\square}$ ) or a sub-maintenance (low, $\square$ ) diet for 69 days. The relative changes in body and testicular mass, expressed as a percentage of the day -1 values, are also provided. Significant effects of diet: ${ }^{* *} P<0.01, * * * P<0.001$. 


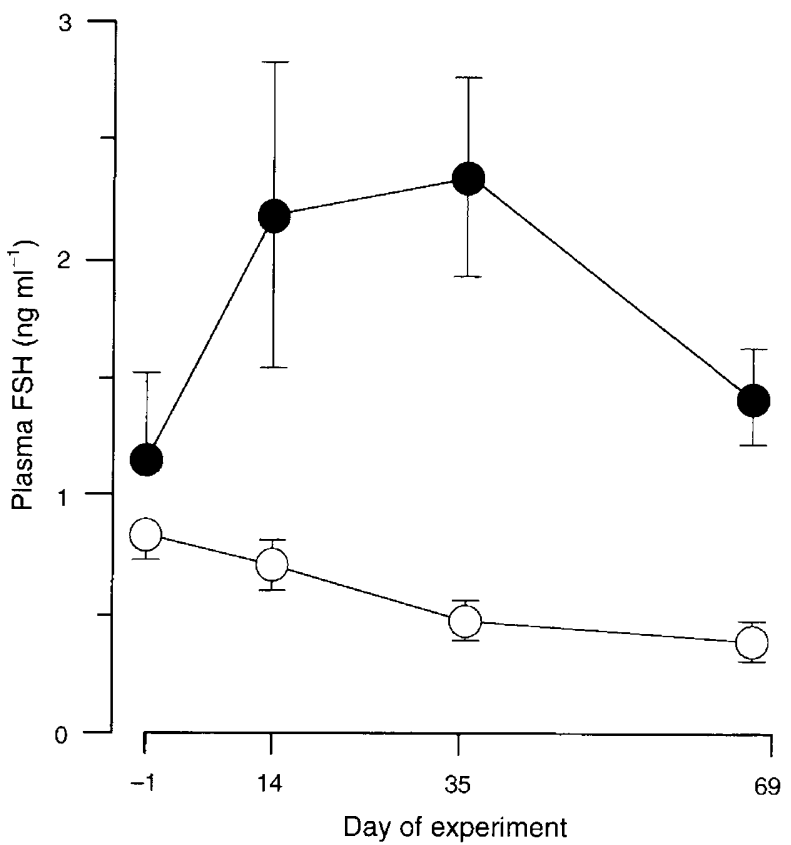

Fig. 2. Mean $\pm \operatorname{SEM}(n=5)$ plasma concentrations of FSH in mature Merino rams fed a supra-maintenance (high, $\mathbf{O}$ ) or a sub-maintenance (low, O) diet for 69 days.

estimated using the areas under the $\mathrm{LH}$ and testosterone curves $(2.1 \pm 0.2$ versus $1.2 \pm 0.2 ; P<0.01)$. However, these differences were not reflected in the testicular vein concentrations or in the testicular: jugular concentration ratio (Fig. 3). When these responses were further studied by analysis of variance for repeated measures, a strong interaction $(P<0.002)$ was revealed between the effect of diet and the effect of time in both the testicular and peripheral circulations. This is evident in the profiles shown (Fig. 4): in rams fed the high diet, the LH injection led to a rapid increase in testosterone concentrations in both veins with peaks at $45-60 \mathrm{~min}$, followed by decreases to pre-injection concentrations by the end of the sampling period. In rams fed the low diet, testosterone concentrations increased more slowly, reached a peak 60-105 min after the LH injection, and then decreased but had not returned to pretreatment values when sampling was stopped. As a result of this difference in the timing of the response, the peak concentration fell outside the period of $15 \mathrm{~min}$ sampling for the animals on the low diet and the final part of their response was not sampled. Consequently, the areas under the response curve differed significantly ( $P<0.01$; Fig. 4) for the jugular vein, and there were similar (but nonsignificant) trends for the response area in the testicular vein and the peak testosterone concentrations (Fig. 4) and in the testicular: jugular concentration ratios (Fig. 3) for both veins, which were calculated from areas under the response curves.

\section{Morphometry and morphology of the testis}

The length and diameter of the seminiferous tubules, but not the diameter of the lumen, were greater in the testes from rams on the high diet than in those from rams on the low diet (Table 1). The absolute volume of seminiferous tubules per testis, and the proportion of the testis taken by this tissue as opposed to interstitial tissue, were affected in the same way (Table I; Fig. 5). The number of Sertoli cell nuclei per testis was also significantly affected by diet, so that more cells were evident in the testis of the rams fed the high diet than in the rams fed the low diet. However, the proportion of the testis occupied by Sertoli cell nuclei was not affected by diet (Table 1).

The total volume of interstitial tissue per testis did not differ significantly between the diets. As a consequence of the change in the volume of seminiferous epithelium, a larger proportion of the testis was occupied by interstitial than by seminiferous tissue in the rams fed the low diet compared with those fed the high diet (Table I; Fig. 5). The relative volume of blood vessels per testis did not differ between the diets, but the rams fed the high diet had a significantly greater absolute volume of blood vessels than the rams fed the low diet (Table 1; Fig. 6). The total volume of lymph vessels tended to be larger in rams fed the high diet than in those fed the low diet. The number of Leydig cells per testis did not differ between the diets, but the total volume occupied by the Leydig cells was greater in rams fed the high diet than it was in rams fed the low diet.

A qualitative assessment showed tubules with a full complement of spermatogenic cells in the testes of all rams, although the numbers appeared to be markedly lower in the rams fed the low diet than in rams fed the high diet (Figs 5 and 6). Infolding of the basement membrane of the seminiferous epithelium was observed in the rams fed the low diet, as a consequence of the reduction in tubule diameter.

\section{Discussion}

This study is the first to describe the morphometric changes on Leydig and Sertoli cells associated with nutrition-induced changes in testicular size, at least for the mature ram. The effects of nutrition on the Sertoli and Leydig cells, two of the major cell types in the testis, are consistent with the changes in output of spermatozoa and hormones that follow nutritioninduced changes in testicular size, as detailed here and in previous studies (for review see Martin and Walkden-Brown, 1995). The absolute volume of Leydig cells was affected by diet but the number of cells per testis was not, suggesting a change in cell size. These changes, added to the effects on testicular vasculature, are consistent with the effects on peripheral and testicular venous concentrations of testosterone observed in the present study. However, not only the size, but also the number of Sertoli cells, differed between the nutritional treatments, contradicting the numerous studies that have suggested that Sertoli cell populations are established before puberty and that these cells subsequently lose their ability to undergo mitosis (Gondos and Berndston, 1993). Since the effects of nutrition on Sertoli cell proliferation in mature males have not been studied in any species with which the present data can be compared, further studies investigating the mitotic potential of Sertoli cells in the adult ram are needed to confirm these findings.

All other observations on the Sertoli cells are consistent with the changes in spermatogenic function that accompany changes in testicular size. The rate of production of spermatozoa is 

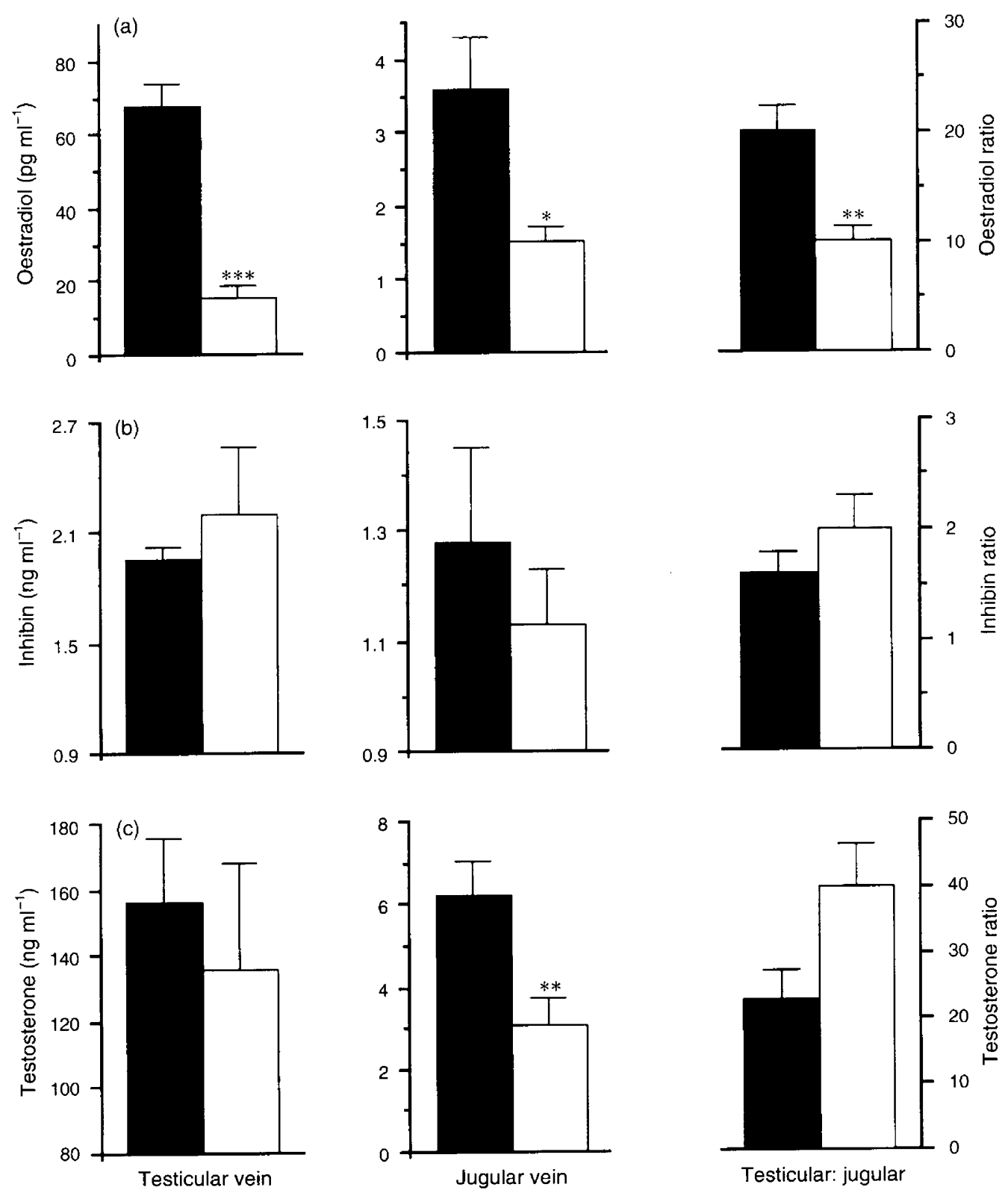

Fig. 3. Mean $\pm \operatorname{SEM}(n=5)$ concentrations of (a) oestradiol, (b) inhibin and (c) testosterone in plasma from jugular and testicular veins, and the ratios of these concentrations in mature Merino rams fed a supramaintenance (high, $\boldsymbol{D}$ ) or a sub-maintenance (low, $\square$ ) diet for 69 days. The concentrations are the means for the samples taken after the injection of exogenous LH. The ratio for testosterone was calculated using the areas under the responses curve. Note the different scales between jugular and testicular vein values. Significant effects of diet: ${ }^{*} P<0.05,{ }^{* *} P<0.01,{ }^{* * *} P<0.001$.

correlated with testicular mass (Amann, 1970; Pomares et al., 1991; Walkden-Brown et al., 1994) and both of these variables are affected by nutrition (Oldham et al., 1978). Similarly, the production of spermatozoa is correlated with the diameter and length of the seminiferous tubules (Pisselet et al, 1984), and thus the amount of seminiferous tissue. Since seminiferous tissue is composed mostly of germ cells, it is arguably no surprise that changes in tubule diameter and length, and thus the amount of seminiferous epithelium, are a major component of the effects of nutrition on testicular mass. The absolute volume of interstitial tissue was not affected, so a larger proportion of the testis was occupied by seminiferous tissue in the rams fed the high than in those fed the low diet. The relative volume of Sertoli cell nuclei per testis was not affected by diet, but the absolute nuclear volume of the Sertoli cells (estimated from the number and volume of cells) differed markedly between the low and high diets $\left(360\right.$ and $600 \mu \mathrm{m}^{3}$, respectively), yet was within the range observed across twelve mammalian species (Russell et al., 1990). Nuclear size is correlated with cell function in Sertoli cells (Hochereau-de Reviers et al., 1976; Sinha Hikim et al., 1988) so the changes in the sizes of Sertoli cell nuclei observed also agree with the changes in 


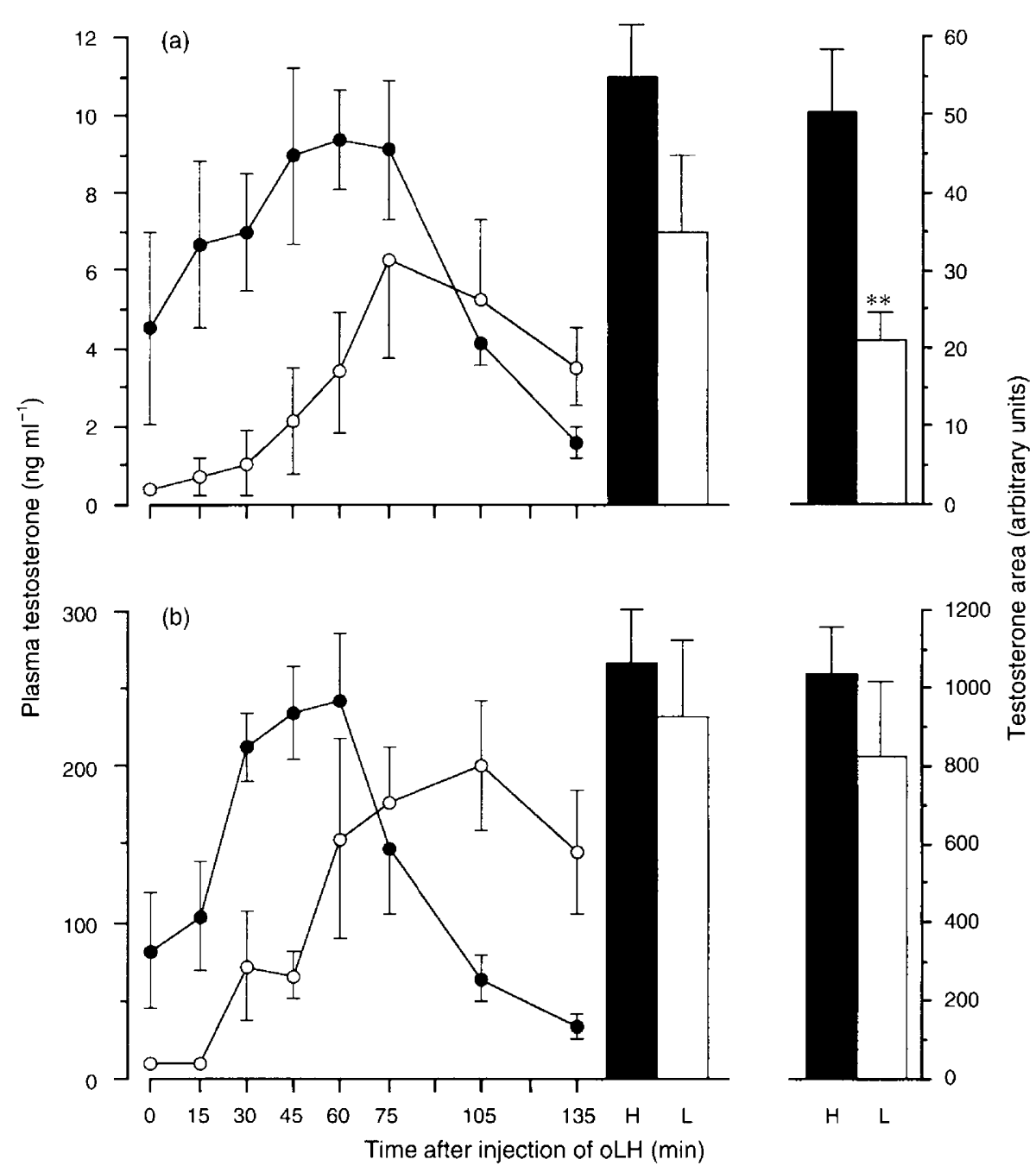

Fig. 4. Concentrations of testosterone in (a) jugular and (b) testicular vein plasma after an injection of ovine LH in mature Merino rams fed a supra-maintenance (high, or a sub-maintenance (low, 0) diet for 69 days. The histograms show the peak concentrations (left) and areas under the testosterone response curve (right) for the high ( $\mathbf{Q}$ ) and low diets ( $\square$ ). Values are mean \pm SEM $(n=5)$. Significant effects of diet: $* * P<0.01$.

sperm production. Merino rams reared under field conditions in Western Australia undergo cyclic changes in testicular size and sperm production but remain fertile throughout the year (Martin, 1984). Consistent with this situation, all the rams presented tubules with spermatogenic cells. The present study only assessed germ cell populations qualitatively, but the low density of germ cells observed in rams fed the low diet suggests that the changes in these rams may have been more marked than those observed in rams under normal field conditions.

The number of Leydig cells per testis was not affected by diet, but the total volume of Leydig cells was, indicating changes in the volume of individual cells. Therefore, an effect of diet on testosterone secretion and the peripheral concentrations of testosterone might be expected. However, in agreement with previous studies (Ritar et al., 1984; Parr and Tilbrook, 1988; Martin et al., 1994a), the amplitude of the testosterone response to $\mathrm{LH}$ was not affected by diet. There were some indications of dietary effects in the other measures of testosterone secretion but the delay in the response to $\mathrm{LH}$ in the rams fed the low diet suggests that these were artefacts. Arguably, this delay, coupled with the long-term nature of the low dietary treatment and the large losses in testicular and body mass, supports the hypothesis that the severity of the dietary treatments explains the apparent disagreements between the early study by Setchell $e$ t al. (1965) showing a significant effect on testosterone secretion and recent work showing no effect on peripheral concentrations (Ritar et al., 1984; Hötzel et al., 1993, 1995; Martin et al., 1994a). However, the effect is at best subtle. Changes in testosterone secretion are correlated with the size and number of Leydig cells, but mostly with the surface area of smooth endoplasmic reticulum in the cytoplasm (Ewing and Zirkin, 1983; Lunstra and Schanbacher, 1988). The regulation of steroidogenic activity also includes changes in the number of $\mathrm{LH}$ receptors per Leydig cell, which influences its sensitivity to LH (Barenton et al., 1983). Further studies describing the effects of nutrition on the LH receptor populations and binding affinities, the ultra- 

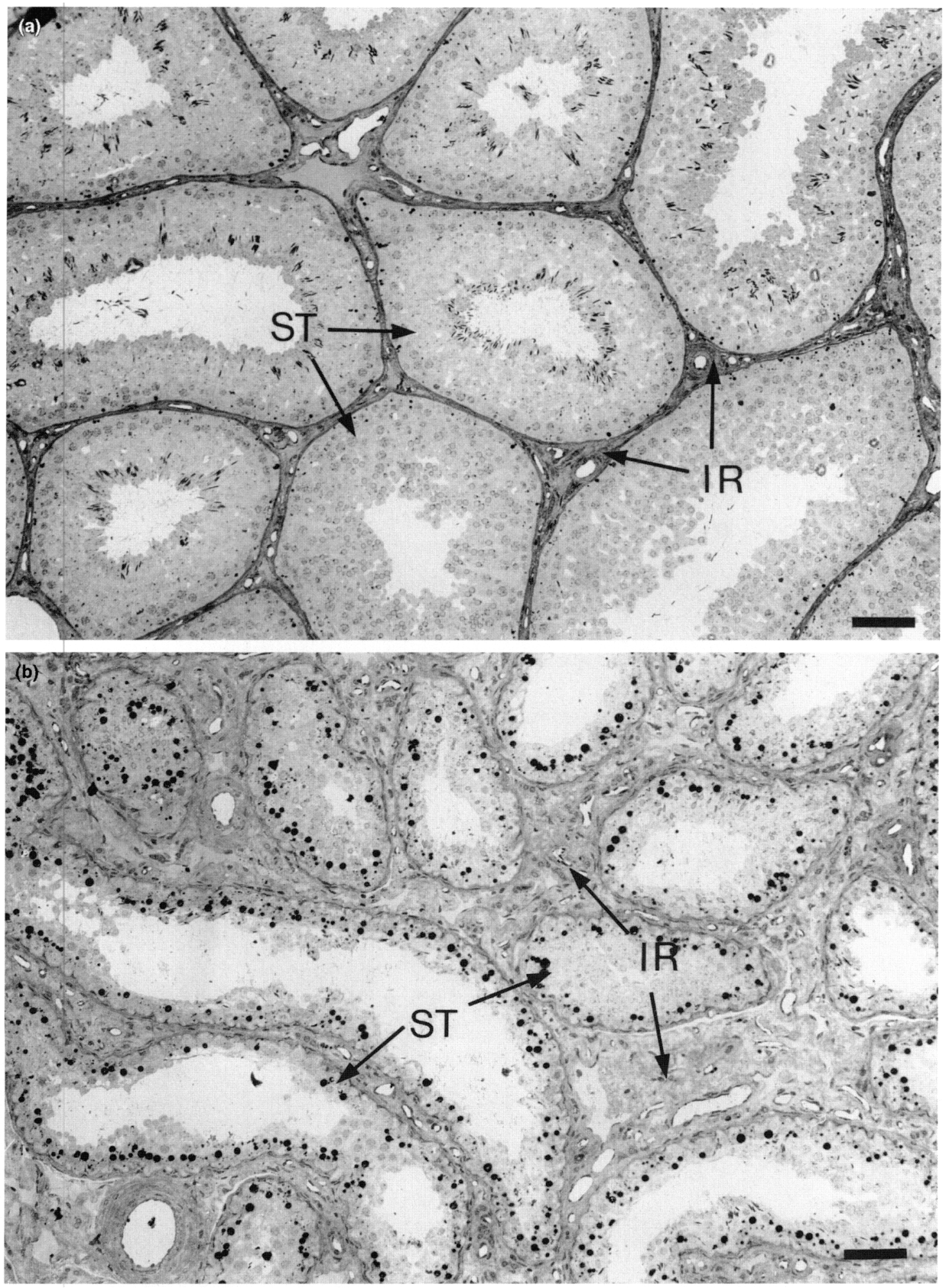

Fig. 5. Photomicrographs showing the interstitial region (IR) and seminiferous tubules (ST) of testes from Merino rams fed (a) a supra-maintenance (high) or (b) a sub-maintenance (low) diet for 69 days. These examples highlight the effect of diet on the size of the seminiferous tubules, and on the relative proportion of the testis occupied by seminiferous and interstitial tissues. Note that in rams on the low diet, spermatogenesis is disrupted in some, but not all, of the tubules. Scale bars represent $70 \mu \mathrm{m}$. 

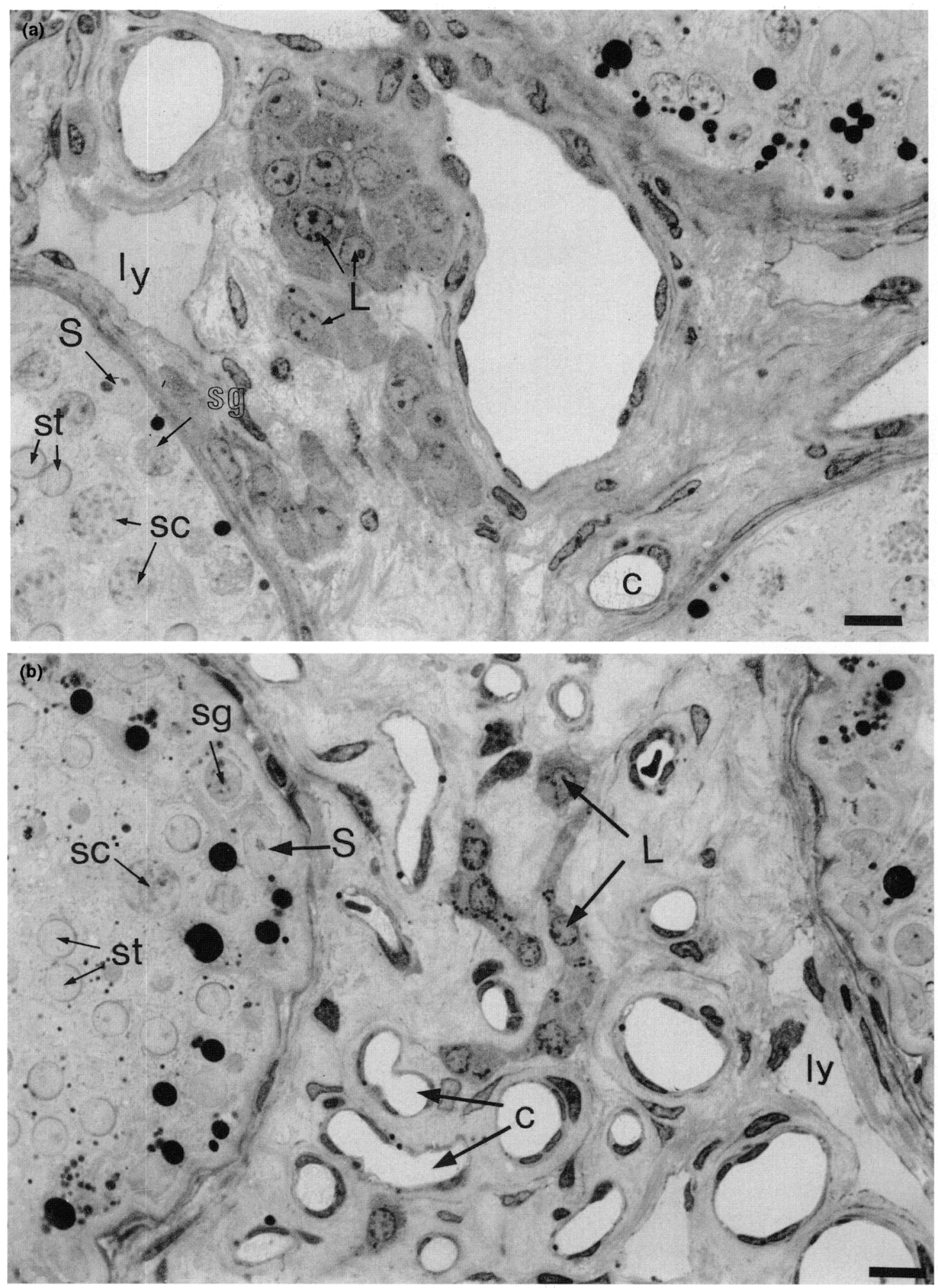

Fig. 6. Photomicrographs showing the interstitial region and seminiferous tubules of testes from Merino rams fed (a) a supra-maintenance (high) or (b) a sub-maintenance (low) diet for 69 days. Leydig cells (L), Sertoli cells (S), capillaries (c), lymph vessels (ly), spermatogonia (sg), spermatocytes (sc) and spermatids (st), are indicated. Scale bars represent $10 \mu \mathrm{m}$.

structure of Leydig cells, and the dynamic aspects of the LH-testosterone relationship are needed. A delay in the testosterone response to $\mathrm{LH}$ is also found in rams immunized against GnRH (Chase et al., 1988), suggesting that long-term deprivation of gonadotrophins underlies the delay we have observed. 
The differences in the concentrations of testosterone in the peripheral circulation, but not in the testicular vein, might also be explained by differences in testicular blood flow. There were large differences in testicular mass between the two groups of rams, and blood flow through the testis is closely related to mass, even when testicular size is affected by nutrition (Setchell et al., 1965) and by other factors such as season, heating and irradiation (Waites and Setchell, 1964; Courot and Joffre, 1977; Wang et al., 1983; Setchell et al., 1991). The relative volume of blood and lymph vessels in the rams was not affected by the diets in the present study, but their absolute volumes increased or decreased as a function of the change in testicular size. These changes in the vasculature of the testis, and the associated changes in testicular blood flow, accommodate the transport of testosterone to the peripheral circulation (Setchell, 1986, 1990). Thus, the present data are in agreement with a previous nutritional study in mature rams (Setchell et al., 1965) and suggest that total blood flow was affected while there was probably little or no change in blood flow per unit mass of testis. As a consequence, larger amounts of testosterone produced by the testis would have reached the peripheral circulation in rams fed the high diet than in those fed the low diet. Nutritional effects on the metabolic clearance of testosterone, another factor that could affect peripheral concentrations of this hormone, have been dismissed by Parr and Tilbrook (1988) and by Tjondronegoro et al. (1996). These authors found similar mean plasma concentrations of testosterone in acutely castrated rams fed different diets and given testosterone implants, although such studies are by no means definitive.

Nutrition affected the number of Sertoli cells counted per testis and the difference between the diets was large and highly significant. This finding is in conflict with the notion that Sertoli cell number is established before puberty in the ram (Monet-Kuntz et al., 1984) and in other species (deer: Hochereau-de Reviers and Lincoln, 1978; rabbit: Gondos and Byskov, 1981; monkey: Kluin et al., 1983; mouse: Kluin et al,, 1984; goat: Hochereau-de Reviers et al., 1986; rat: Steinberger and Steinberger, 1971; Orth, 1982; hamster: Russell et al., 1994). However, there have been reports of changes after puberty. For example, prepubertal cryptorchidism has been associated with increases in the number of Sertoli cells per testis after the onset of puberty in boys and lambs (Läckgren and Plöen, 1984; Monet-Kuntz et al., 1987). Marshall and Plant (1996) have reported a sixfold greater Sertoli cell population in adult than in juvenile Rhesus monkeys, and found a similar change when puberty was induced precociously with pulsatile GnRH. In stallions, the number of Sertoli cells per testis appears to be affected by season (Johnson and Thompson, 1983; Johnson and Tatum, 1989; Johnson et al., 1991). The present study is the first to investigate the effect of nutrition on Sertoli cell populations in mature rams and the results suggest that the Sertoli cell of rams retains some mitotic potential during adulthood, and that factors that mediate the effect of nutrition on testicular growth trigger replication of this cell. Studies on the mitotic potential of Sertoli cells in adult rams are needed to confirm the present findings, perhaps using biochemical markers of Sertoli cell function.

The diets exerted large effects on plasma concentrations of FSH and on testicular mass, but not on plasma concentrations of inhibin, in agreement with previous reports (Martin et al., 1994a; Hötzel et al., 1995). This cannot be explained by effects on the metabolic clearance of inhibin, because similar effects of diet were observed in castrated rams given exogenous inhibin (Tjondronegoro et al., 1996). The inhibin concentrations were not correlated with changes in the Sertoli cell population or nuclear volume, although these variables do not appear to be closely related. For example, in Soay rams, a 30\% increase in Sertoli nuclear size induced by photoperiod is translated into a fourfold increase in plasma concentrations of inhibin (Hochereau-de Reviers et al., 1985; Lincoln and McNeilly, 1989). The twofold difference between the concentrations of inhibin in testicular and jugular plasma is similar to that reported by Tilbrook et al. (1991) and suggests that the testis is the major source of inhibin, although there is still some controversy in the literature concerning this. Some studies of plasma from castrated rams have found inhibin (Schanbacher, 1988; Clarke et al., 1991), while another did not (Lincoln and McNeilly, 1989). This discrepancy is probably related to the different antibodies used for the inhibin assay. Moreover, the radioimmunoassays that have been used to measure ovine inhibin detect the free $\alpha$-subunit which does not have biological activity (Findlay et al., 1992). The data from the present and other studies must be interpreted with caution.

The finding that concentrations of oestradiol are 10-20-fold higher in plasma from testicular veins than in plasma from jugular veins is in agreement with other studies that suggest that large amounts of this hormone are synthesized in the testis of prepubertal and adult rams (Pope et al., 1990; Setchell et al., 1991). In contrast with its effect on testosterone and inhibin, diet had a large effect on both peripheral and testicular vein concentrations of oestradiol, and also affected the ratio of peripheral: testicular concentrations. These findings suggest that nutrition influences the rate of aromatization of testosterone to oestradiol, or its metabolic clearance. The clearance of oestradiol has been reported to be lower in undernourished than in well-fed ewes (Adams et al., 1994). However, in rams, the site of production of oestradiol has not been established so the effect of diet may be related to the morphological changes in Sertoli or Leydig cells.

Plasma FSH concentrations increased shortly after the change in diet in rams fed the high diet and returned to the initial concentrations by the end of the study. However, they remained higher than those in the rams fed the low diet, which were depressed throughout. The effects. in the high diet group are in agreement with previous studies (Martin et al., 1994a; Hötzel et al., 1995, 1997) but the persistently low concentrations in the rams fed the low diet do not. The severity and longer duration of undernutrition used in the present study probably explain the different findings: for example, the 'underfed' rams used by Martin et al. (1994a) stopped losing body mass after a few weeks on their 'low' diet.

The effects of nutrition on the interstitial and seminiferous compartment of the testis are consistent with the poor association between long-term changes in LH secretion and nutrition-induced testicular growth (Martin et al., 1994a; Hötzel et al., 1995). Such observations suggest that part of the effect of nutrition on testicular growth is independent of changes in GnRH pulsatility (Ritar et al., 1984; Martin et al., 1987, 1994a). This is supported by recent studies showing that, when GnRH pulse frequency is held constant, nutrition has still some effect 
on testicular size (Hötzel et al., 1995, 1997). An inconsequential effect of nutrition on LH secretion is consistent with the very small effects on testosterone secretion, compared with other factors that affect testicular growth, such as maturation and photoperiod (Lincoln, 1979; Lincoln and Short, 1980; MonetKuntz et al., 1984). The slow seasonal increase in LH release was shown to be necessary to upregulate the number of testicular LH receptors to result in increased testosterone secretion (Barenton and Pelletier, 1983) and in vivo and in vitro studies suggest that the ability of the Leydig cell to secrete testosterone is more affected by the basal or mean concentrations of LH than by the dynamic changes in LH concentrations to which these cells are exposed (Chase et al., 1988, 1992). The effects of nutrition on the number of Sertoli cells, should they be confirmed, are also consistent with their endocrine regulation. A change in cell population cannot be related to changes in $\mathrm{LH}$ and FSH secretion, given the poor correlation between changes in plasma gonadotrophin concentrations and the number of Sertoli cells under a variety of situations that alter testicular size markedly, such as maturational growth (Monet-Kuntz et al., 1984), reproductive cycles driven by photoperiod (Hochereau-de Reviers, 1985, 1992) and hemicastration (Mirando et al, 1989). This is further highlighted by the total absence of effects on number of Sertoli cells, even when the testis is totally deprived of gonadotrophins by hypophysectomy or passive immunization against FSH (Hochereau-de Reviers and Courot, 1978; Courot et al., 1984; Kilgour et al., 1993). However, the regulation of testicular growth by nutrition involves a variety of peripheral metabolic substances and hormones (Martin et al., 1992), and it is plausible that, if mitotic activity is maintained in adult rams, it is triggered by GnRH-independent cues not normally made available by factors other than nutrition. In general, the effects of nutrition on the seminiferous and interstitial compartments of the testis are consistent with its effects on LH and FSH secretion, and the relatively greater importance of FSH over LH in the long-term control of spermatogenesis in rams (Courot, 1988; Kilgour et al., 1993).

In conclusion, the findings of the present study concerning the effects of nutrition on the Leydig and Sertoli cells are entirely consistent with the effects on the endocrine and exocrine function of the testis reported here and elsewhere. Furthermore, many of the effects observed lend support to our previous studies investigating the pathways involved in mediating the effects of nutrition on testicular growth. The surprising finding that Sertoli cell population was altered in adult rams might be explained by the GnRH-independent effects of nutrition. The relatively small effect on Leydig cell volume and testosterone production when compared with, for example, similar changes in testicular size induced by photoperiod is consistent with the short-lived effects of changes in diet on LH pulse frequency. Similarly, the change in testicular size induced by nutrition is accounted for almost entirely by changes in the seminiferous compartment of the testis, consistent with the more powerful and relatively longer lasting effects nutrition has on FSH than it has on LH secretion.

The authors are grateful to the National Institute of Diabetes, Digestive and Kidney Disease, the Center for Population Research of the National Institute of Child Health, and the Agricultural Research
Service of the US, Department of Agriculture, as well as to the University of Maryland School of Medicine, for the reagents for the FSH assays. They would like to acknowledge R. I. Cox (CSIRO Division of Animal Production, Prospect, NSW) for the donation of testosterone-3-CMO-HSA and D. Blache for helping with the animal work. They are particularly indebted to J. B. Kerr (Monash University) for guidance with the histology, and to G. T. Meyer (Anatomy and Human Biology, University of Western Australia) for advice and use of his facilities. M. T. Hochereau de Reviers also offered very useful advice, although she might not agree with all of our observations! This work was funded by the Australian Research Council. M. J. Hötzel was supported by the Brazilian Research Council (CNPq) and S. W. Walkden-Brown by the EHB Lefroy Fellowship.

\section{References}

Adams NR, Briegel JR and Sanders MR (1994) Effect of diet on the clearance of estradiol-17 $\beta$ in the ewe Biology of Reproduction 51 668-674

Alkass JE, Bryant MJ and Walton JS (1982) Some effects of level of feeding and body condition upon sperm production and gonadotropin concentrations in the ram Animal Production 34 265-277

Amann RP (1970) Sperm production rates. In The Testis. Vol. 1. Development, Anatomy, and Physiology pp 433-481 Eds WR Gromes, NL Van Demark and AD Johnson. Academic Press

Barenton B and Hochereau-de Reviers MT (1981) Effects of photoperiod and induced-hypoprolactinaemia on gonadotrophin receptors in the ram testis International Journal of Andrology Supplement 325

Barenton B and Pelletier J (1983) Seasonal changes in testicular gonadotropin receptors and steroid content in the ram Endocrinology 112 1441-1446

Barenton B, Hochereau-de Reviers MT, Perreau C and Saumande J (1983) Changes in testicular gonadotropin receptors and steroid content throughout postnatal development until puberty in the lamb Endocrinology 112 1447-1453

Braden AWH, Turnbull KE, Mattner PE and Moule GR (1974) Effect of protein and energy content of the diet on the rate of sperm production in rams Australian Journal of Biological Sciences $2767-73$

Cameron AWN, Murphy PM and Oldham CM (1988) Nutrition of rams and output of spermatozoa Proceedings of the Australian Society of Animal Production $17162-165$

Chase DJ, Schanbacher BD and Lunstra DD (1988) Effects of pulsatile and continuous luteinizing hormone $(\mathrm{LH})$ infusions on testosterone responses to LH in rams actively immunised against gonadotrophin-releasing hormone Endocrinology 123 816-826

Chase DJ, Karle JA and Fogg RE (1992) Maintenance or stimulation of steroidogenic enzymes and testosterone production in rat Leydig cells by continuous and pulsatile infusions of luteinizing hormone during passive immunization against gonadotrophin-releasing hormone Journal of Reproduction and Fertility $95657-667$

Clarke IJ, Tilbrook AJ, Galloway DB, Earl CR, Findlay JK and De Kretser DM (1991) Inhibin in rams Joumal of Reproduction and Fertility Supplement $\mathbf{4 3}$ $163-170$

Courot M (1988) The effects of gonadotrophins on testicular function (spermatogenesis) Proceedings of the 11th International Congress on Animal Reproduction and Artificial Insemination, University College Dublin 5 311-319

Courot M and Joffre M (1977) Testicular capillary blood flow in the impubertal lamb and ram during the breeding and non-breeding seasons Annales de Biologie Animale, Biochimie et Biophysique 16171

Courot M, Hochereau-de Reviers MT, Pisselet C, Kilgeur RJ, Dubois MP and Sairam MR (1984) Effect of passive immunisation against ovine $\beta$-FSH on spermatogenesis in the ram. In The Male in Farm Animal Reproduction pp 75-79 Ed. M Courot. Martinus Nijhoff Publishers, Lancaster

Ewing LL and Zirkin B (1983) Leydig cell structure and steroidogenic function Recent Progress in Hormone Research 39 599-635

Findlay JK, Robertson DM, Clarke IJ, Klein R, Doughton BW, Wiao S, Russell DL and Shukovski L (1992) Hormonal regulation of reproduction - general concepts Animal Reproduction Science 28 319-328

Gondos B and Byskov AG (1981) Germ cell kinetics in the neonatal rabbit testis Cell Tissue Research 215 143-151

Gondos B and Berndston WE (1993) Postnatal and pubertal development. In The Sertoli Cell Ist Edn pp 115-154 Eds LD Russell and MD Griswold. Cache River Press, Clearwater, FL 
Hochereau-de Reviers MT and Courot M (1978) Sertoli cells and development of the seminiferous epithelium Annales de Biologie Animale, Biochimie ef Biophysique 18 573-583

Hochereau-de Reviers MT and Lincoln GA (1978) Seasonal variation in the histology of the testis of the red deer, Cervus elaphus. Journal of Reproduction and Fertility 54 209-213

Hochereau-de Reviers MT, Loir M and Pelletier J (1976) Seasonal variations in the response of the testis and LH levels to hemicastration of adult rams Journal of Reproduction and Fertility 46 203-209

Hochereau-de Reviers MT, Perreau C and Lincoln GA (1985) Photoperiodic variations of somatic and germ cell populations in the soay ram testis Journal of Reproduction and Fertility 74 329-334

Hochereau-de Reviers MT, Perreau C, Delouis C, Chemineau P and Courot M (1986) Effects of photoperiod during foetal life and age on total number of Sertoli cells per testis between birth and adulthood in the goat Biology of Reproduction 1 Supplement 234 Abstract 369

Hochereau-de Reviers MT, Perreau C, Pisselet C and Monet-Kuntz C (1990) Comparisons of endocrinological and testis parameters in 18 month old lle de France and Romanov rams Domestic Animal Endocrinology 7 63-73

Hochereau-de Reviers MT, Perreau C, Pisselet C and Pelletier J (1992) Effect of a 2-month light cycle regimen on testicular parameters of adult Ile-de-France rams Microscopy Research and Technique 20 268-273

Hötzel MJ, Martin GB and Markey CM (1993) Effect of nutrition on testicular function of rams immunised against GnRH Proceedings of the Endocrine Society of Australia 36102

Hötzel MJ, Walkden-Brown SW, Blackberry MA and Martin GB (1995) The effect of nutrition on testicular growth in mature Merino rams involves mechanisms that are independent of changes in GnRH pulse frequency Journal of Endocrinology 147 75-85

Hötzel MJ, Martin GB and Caraty A (1997) Effect of nutrition on testicular growth in mature Merino rams actively immunized against GnRH journal of Reproduction and Fertility 110 195-204

Johnson L and Thompson DL (1983) Age-related and seasonal variation in the Sertoli cell population, daily sperm production and serum concentrations of follicle-stimulating hormone, luteinizing hormone and testosterone in stallions Biology of Reproduction 29 777-789

Johnson L and Tatum ME (1989) Temporal appearance of seasonal changes in numbers of Sertoli cells, Leydig cells and germ cells in stallions Biology of Reproduction 40 994-999

Johnson L, Dickson DV, Tatum ME and Scrutchfield WL (1991) Season but not age affects Sertoli cell number in adult stallions Biology of Reproduction 45 $404-410$

Kilgour RJ, Courot M, Pisselet C, Dubois MP and Sairam MR (1993) Inhibition of FSH affects spermatogenesis in the mature ram Animal Reproduction Science 32 213-225

Kluin PM, Kramer MF and de Rooij DG (1983) Testicular development in Macaca irus after birth International Journal of Andrology 6 25-43

Kluin PM, Kramer MF and de Rooij DG (1984) Proliferation of spermatogonia and Sertoli cells in maturing mice Anatomy and Embryology 169 73-78

Läckgren G and Plöen L (1984) The morphology of the human undescended testis with special reference to the Sertoli cell and puberty International Journal of Androlosy 7 23-38

Lincoln GA (1979) Differential control of luteinizing hormone and folliclestimulating hormone by luteinizing hormone releasing hormone in the ram Journal of Endocrinology 80 133-140

Lincoln GA and McNeilly AS (1989) Inhibin concentrations in the peripheral blood of rams during a cycle in testicular activity induced by changes in photoperiod or treatment with melatonin Journal of Endocrinology 120 R9-I3

Lincoln GA and Short RV (1980) Seasonal breeding: nature's contraceptive Recent Progress in Hormone Research 36 I-52

Lunstra DD and Schanbacher BD (1988) Testicular function and Leydig cell ultrastructure in long-term bilaterally cryptorchid rams Biology of Reproduction 38 211-220

McNeilly A, Swanston I, Crow W, Tsonis C and Baird D (1989) Changes in the plasma concentrations of inhibin throughout the normal sheep oestrous cycle and after the infusion of FSH Journal of Endocrinology 120 295-305

Maddocks S, Hargreave TB, Reddie K, Fraser HM, Kerr JB and Sharpe RM (1993) Intratesticular hormone levels and the route of secretion of hormones from the testis of the rat, guinea pig, monkey and human International Journal of Andrology $16 \quad 272-278$

Marshall GR and Plant TM (1996) Puberty occurring either spontaneously or induced precociously in Rhesus monkeys (Macaca mulata) is associated with a marked proliferation of Sertoli cells Biology of Reproduction 54 1192-1199
Martin GB (1984) Factors affecting the secretion of luteinizing hormone in the ewe Oxford Reviews of Reproductive Biology 59 I-87

Martin GB and Walkden-Brown SW (1995) Nutritional influences on reproduction in mature male sheep and goats Journal of Reproduction and Fertility Supplement 49 4.37-449

Martin GB, Sutherland SRD and Lindsay DR (1987) Effects of nutritional supplements on testicular size and the secretion of $\mathrm{LH}$ and testosterone in Merino and Booroola rams Animal Reproduction Science 12 267-281

Martin GB, Boukhliq R, Tjondronegoro S, Hötzel MJ and Fisher IS (1992) The effects of nutrition on reproductive endocrinology Proceedings of the Nutrition Society of Australia 17 177-185

Martin GB, Tjondronegoro S and Blackberry MA (1994a) Effects of nutrition on testicular size and the plasma concentrations of gonadotrophins, testosterone and inhibin in mature male sheep Journal of Reproduction and Fertility 101 $121-128$

Martin GB, Walkden-Brown SW, Boukhliq R, Tjondronegoro S, Miller DW, Fisher JS, Hötzel MJ, Restall BJ and Adams NR (1994b) Non-photoperiodic inputs into seasonal breeding in male ruminants. In Perspectives in Comparative Endocrinology pp 574-585 Eds KG Davey, RE Peter and SS Tobe. National Research Council of Canada, Ottawa

Masters DG and Fels HE (1984) Seasonal changes in the testicular size of grazing rams Proceedings of the Australian Society of Animal Production 15 $444-447$

Mirando MA, Hoagland TA, Woody Jr CO and Riesen JW (1989) The influence of unilateral castration on testicular morphology and function in adult rams Biology of Reproduction 41 798-806

Monet-Kuntz C, Hochereau-de Reviers MT and Terqui M (1984) Variations in testicular androgen receptors and histology of the lamb testis from birth to puberty Journal of Reproduction and Fertility 70 203-210

Monet-Kuntz C, Barenton B, Locatelli A, Fontaine I, Pereau C and Hochereau-de Reviers MT (1987) Effects of experimental cryptorchidism and subsequent orchidopexy on seminiferous tubule functions in the lamb Journal of Andrology 8 148-154

Moule GR (1963) Postpubertal nutrition and reproduction by the male Australian Veterinary Journal 39 299-304

Noordhuizen-Stassen EN, Charbon GA, de Jong FH and Wensing CJG (1985) Functional arterio-venous anastomoses between the testicular artery and the pampiniform plexus in the spermatic cord of rams Journal of Reproduction and Fertility 75 193-201

Oldham CM, Adams NR, Gherardi PB, Lindsay DR and Mackintosh JB (1978) The influence of level of feed intake on sperm-producing capacity of testicular tissue in the ram Australian Journal of Agricultural Research 29 173-179

Orth JM (1982) Proliferation of Sertoli cells in fetal and postnatal rats: a quantitative autoradiographic study Anatomical Record 203 485-492

Parker GV and Thwaites CJ (1972) The effects of undernutrition on libido and semen quality in adult Merino rams Australian Journal of Agricultural Research 23 109-115

Parr RA and Tilbrook AJ (1988) The influence of nutrition on circulating levels of testosterone in rams and testosterone treated wethers Proceedings Australian Society of Animal Production 18 328-331

Pisselet C, Perreau C and Hochereau-de Reviers MT (1984) Relationship between rete testis fluid secretion and testicular structure in the ram Reproduction, Nutrition, Développement 24 483-486

Pomares CC, Galloway DB, Holmes JHC, Tilbrook AJ and Clarke IJ (1991) The effects of lupin and cowpea supplements on reproductive characteristics in rams Proceedings of the Australian Society for Reproductive Biology 2380

Pope GS, Cunningham JM, Jenkins N, Waites GMH and Watts GE (1990) Oestradiol-17 $\beta$ in the testis and jugular venous plasma of intact and hemi-castrated prepubertal lambs and in jugular venous plasma of castrated prepubertal lambs Animal Reproduction Science 22 9-19

Ritar AJ, Adams NR and Sanders MR (1984) Effect of lupin feeding on LH, testosterone and testes. In Reproduction in Sheep pp 76-48 Eds DR Lindsay and DT Pearce. Australian Academy of Science, Canberra

Russell LD, Ping Ren H, Shinha-Hikim I, Shulze W and Shinha-Hikim AP (1990) A comparative study in twelve mammalian species of volume densities, volumes and numerical densities of selected testis components, emphasizing those related to the Sertoli cell American Journal of Anatomy 188 21-30

Russell LD, Chandrashekar V, Bartke A and Sinha Hikim AP (1994) The hamster Sertoli cell in early regression and early recrudescence: a stereological and endocrine study International Journal of Andrology 17 93-106

Salamon S (1964) The effect of nutritional regimen on the potential semen production of rams Australian Journal of Agricuilural Research 15 645-656 
Schanbacher BD (1988) Radioimmunoassay of inhibin: serum responses to unilateral and bilateral orchidectomy Endocrinology 123 2323-2330

Setchell BP (1986) The movement of the fluids and substances in the testis Australian Journal of Biological Sciences 39 193-207

Setchell BP (1990) Local control of testicular fluids Reproduction, Fertility and Development 2 291-309

Setchell BP, Waites GMH and Lindner HR (1965) Effect of undernutrition on testicular blood flow and metabolism and the output of testosterone in the ram Journal of Reproduction and Fertility 9 149-162

Setchell BP, Waites GMH and Thorburn MB (1966) Blood flow in the testis of the conscious ram measured with krypton: effects of heat, catecholamines and acetylcholine Circulation Research 18 755-764

Setchell BP, Locatelli A, Perreau C, Pisselet C, Fontaine I, Kuntz C, Saumande J, Fontaine J and Hochereau-de Reviers MT (1991) The form and function of the Leydig cells in hypophysectomized rams treated with pituitary extract when spermatogenesis is disrupted by heating the testes Journal of Endocrinology 131 101-112

Sinha Hikim AP, Bartke A and RusselI LD (1988) Morphometric studies on hamster testes in gonadally active and inactive states: light microscope findings Biology of Reproduction 39 1225-1237

Steinberger A and Steinberger E (1971) Replication pattern of Sertoli cells in maturing rat testis in vivo and in organ culture Biology of Reproduction 4 84-87

Tilbrook AJ, de Kretser DM and Clarke IJ (1991) Studies on the source of inhibin and its route of secretion in rams: failure of the Leydig cell to secrete inhibin in response to a human chorionic gonadotrophin/LH stimulus Journal of Endocrinology 130 107-114

Tjondronegoro S, Martin GB, Sutherland SRD and Boukhliq R (1996) Interactions between nutrition, testosterone and inhibin in the control of gonadotrophin secretion in mature rams Reproduction, Fertility and Development 8 855-862

Waites GMH and Setchell BP (1964) Effect of local heating on blood flow and metabolism in the testis of the conscious ram Journal of Reproduction and Fertility 8 339-349

Walkden-Brown SW, Restall BJ and Taylor WA (1994) Testicular and epididymal sperm content in Australian cashmere bucks: seasonal variation and prediction from in vivo measurements Reproduction, Fertility and Devlopment 6 $727-736$

Wang J, Galil KAA and Setchell BP (1983) Changes in testicular blood flow and testosterone production during aspermatogenesis after irradiation Journal of Endocrinology 98 35-46

Webb R, Baxter G, McBride D, Nordblom GD and Shaw MPK (1985) The measurement of testosterone and oestradiol-17 $\beta$ using iodinated tracers and incorporating an affinity chromatography extraction procedure Journal of Steroid Biochemistry 23 1043-1051

Weibel ER (1979) Stereological methods. In Practical Methods for Biological Morphometry Academic Press, London

Wensing CJG, Dijkstra G and Frankenhuis MT (1981) The intricate morphological relations between testicular artery and pampiniform plexus International Journal of Andrology Supplement 3 77-78 